\title{
Methodology for determining the investment attractiveness of construction of high-rise buildings
}

\author{
Ekaterina Nezhnikova ${ }^{1, *}$ Valentin Kashirin ${ }^{2}$, Yana Davydova $^{3}$, and Svetlana Kazakova ${ }^{3}$ \\ ${ }^{1}$ Peoples' Friendship University of Russia (RUDN University), Miklukho-Maklaya Street, 6, \\ Moscow, 117198, Russia \\ (The publication was prepared with the support of the "RUDN University Program 5-100") \\ ${ }^{2}$ Moscow Aviation Institute (National Research University), Volokolamskoe highway, 4, Moscow, \\ 125993, Russia \\ ${ }^{3}$ Moscow humanitarian-economic University, Leninsky highway, 8/16, Moscow, 119049, Russia
}

\begin{abstract}
The article presents the analysis of the existing methods for assessing the investment attractiveness of high-rise construction. The authors determined and justified the primary choice of objects and territories that are the most attractive for the development of high-rise construction. A system of risk indicators has been developed that allow making a quantitative adjustment for a particular project in the evaluation of the efficiency of investment projects. The study is aimed at developing basic methodological concepts for a comparative evaluation of the prospects of construction of high-rise facilities that allow to take into consideration the features of investment in construction and to enable quantitative evaluation of the investment effectiveness in high-rise construction.
\end{abstract}

\section{Introduction}

Although there is a number of different methods for assessing investment attractiveness and the riskiness of certain projects, it is not always possible to use them because of their "general" nature. The industry specificity of a particular business is negligibly taken into account, the types of objects are not considered, there is no linkage to specific strategic priorities and tasks. Thus, traditionally used methods for assessing the investment attractiveness of high-rise construction are based on the macro level analysis.

Investors evaluate the attractiveness of projects in comparison with alternative investment options. Estimating investment potential, the investor brings his subjective view in its description, considering attractive and prospective the one that best meets his ideas and expectations. As a result, the concept of investment attractiveness can be formulated as an investor's subjective assessment of the region, formed on the basis of an analysis of the objective characteristics of the investment climate [1].

\footnotetext{
*Corresponding author: katnej@mail.ru
} 


\section{Materials and Methods}

The study of such approaches to analyzing investment potential as financial, resultant, resource, etc., has shown that investment potential is a complex of investment opportunities that is formed due to integration and synergy of infrastructure, resource and macroeconomic potentials, limited by the level of investment risks [2].

The total investment potential of the system includes the following components:

- $\quad$ Resource and raw component: provision of the territory with balance reserves of the main types of natural resources;

- Production component: the aggregate result of the economic activity of the population in the region;

- Consumer component: aggregate purchasing power of the population of the region;

- Infrastructural component: economic and geographic location of the region and its infrastructural saturation;

- Innovative component: the level of science development, the introduction of scientific and technological progress and the level of manufacture modernization in the region.

- Labor component: availability of professionally trained labor and qualified engineering staff.

- Institutional component: providence of the development of the region with the necessary institutions of a market economy.

- Financial component: the volume of the tax base and the profitability of enterprises.

The authors suppose, that the structural approach should be complemented with institutional components. As practice shows, a favorable investment climate is not sufficient for the attractiveness of the project without taking into account measures that stimulate investment activity. Therefore, when assessing, due attention should be paid to the state participation in the investment climate development. A generalized scheme of the relationship between the elements of the investment process is shown in Fig. 1.

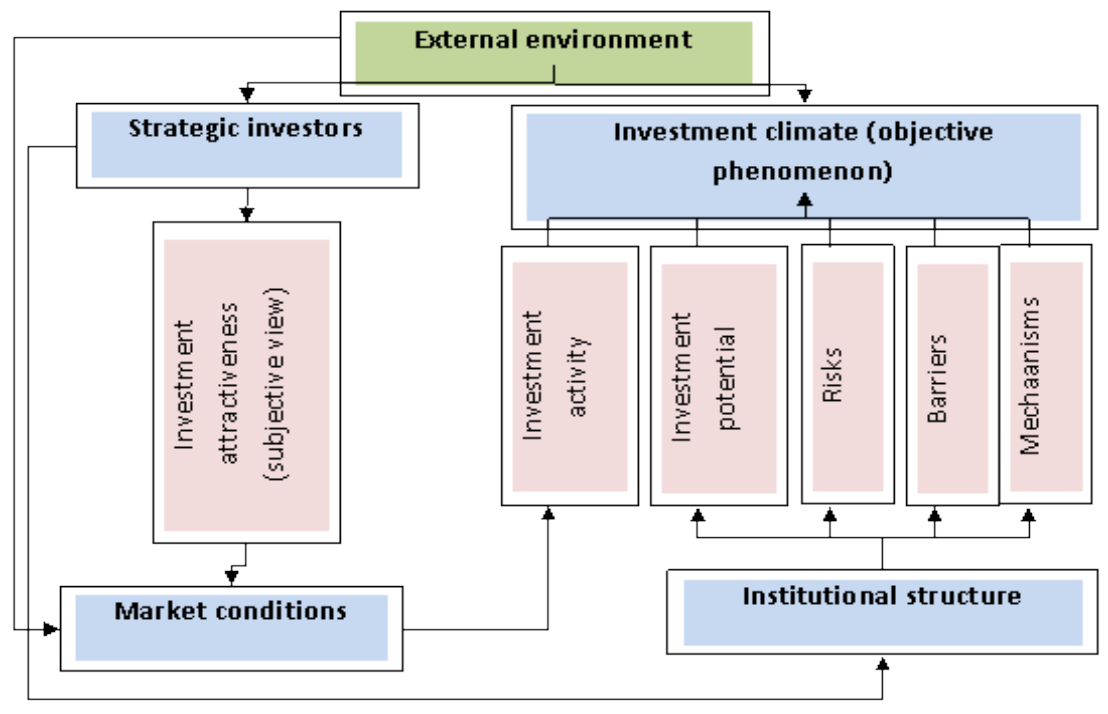

investigation of investor preferences

Fig. 1. Interrelation of elements of investment process 
A large number of studies and publications are aimed at the issues of investment climate assessment. Each method satisfies the preferences of a certain "consumer". Consequently, in each case it determines its own set of basic factors and indicators, as well as the approach to the organization of the research process, etc. As a result of the analysis of these sources, a classification of methods for assessing the investment attractiveness of economic systems was made (Figure 2).

The assessment of the investment climate in terms of methodological approach is the most commonly used classification. There are three most distinctive approaches [3]:

1. Constricted approach: the calculation uses the indicator of the level of profitability of the used assets;

2. Factor approach: the identification of a set of influencing factors and the determination of the weighted average estimate;

3. Risk approach: risks are assessed in terms of the possibility of investment losses and income on them.

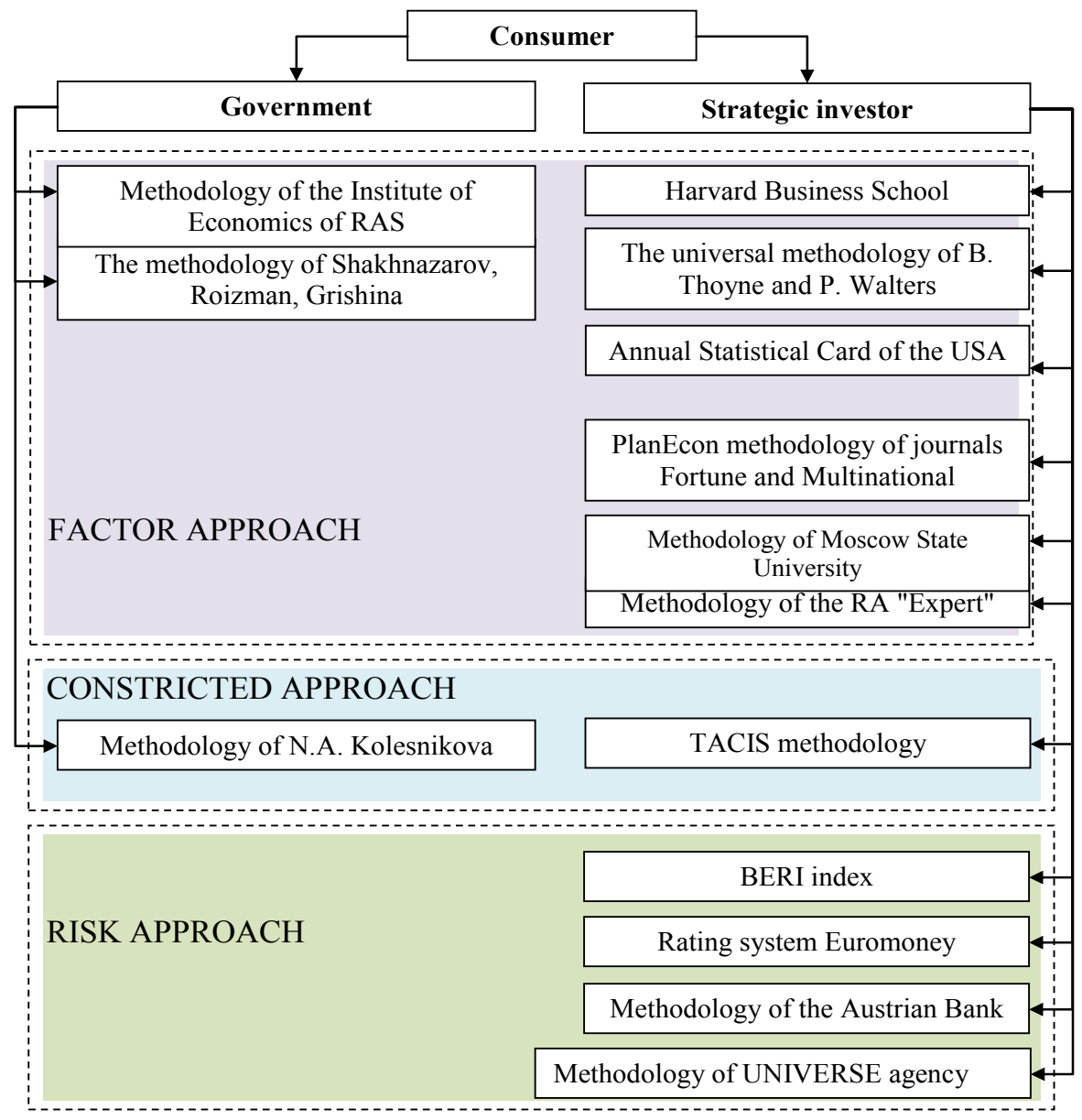

Fig. 2. Classification of methodologies for assessing the investment attractiveness of economic systems

All methods imply consideration of a set of various factors that influence the prospects of investment projects. The number of these factors, their specifics and structure, the methods of evaluation, the methods of measurement, the weights of the factors vary considerably and represent positions of certain methodologies and the certain specifics of application. 
However, the following conclusions can be made in general:

1. There is no unified international or even national standard for a comparative assessment of the investment attractiveness of high-rise construction projects.

2. There is a limited set of indicators to be considered, which does not take into account the differentiation of the regions of the Russian Federation.

3. The generalized estimate does not take into account the significant factors of attractiveness of high-rise construction projects in a particular case.

4. There is no account of the legislative conditions for investment, especially in the part of regional and local legislation.

5. There is no clear justification for the principles of aggregation of a set of valuation indicators.

6. There is uncertainty about the period of research.

7. Often the methods are of a general nature, they do not take into account the sectorial specifics and priorities of certain groups of investors.

\section{Results}

Within the research the authors offer methodical concepts of an estimation of investment attractiveness of high-rise construction projects for choosing a building companies' development directions. The elaborated approach includes both qualitative and quantitative analysis for a number of key factors that reflect the specifics of the industry and specific markets [4].

The methodology assumes a two-dimensional assessment: at the first stage, the investment attractiveness of the territory is determined, which enabled the initial selection of areas of territorial expansion; on the second stage investment criteria are adjusted to the degree of risks. The methodology involves eight consecutive stages, which are shown in Fig. 3.

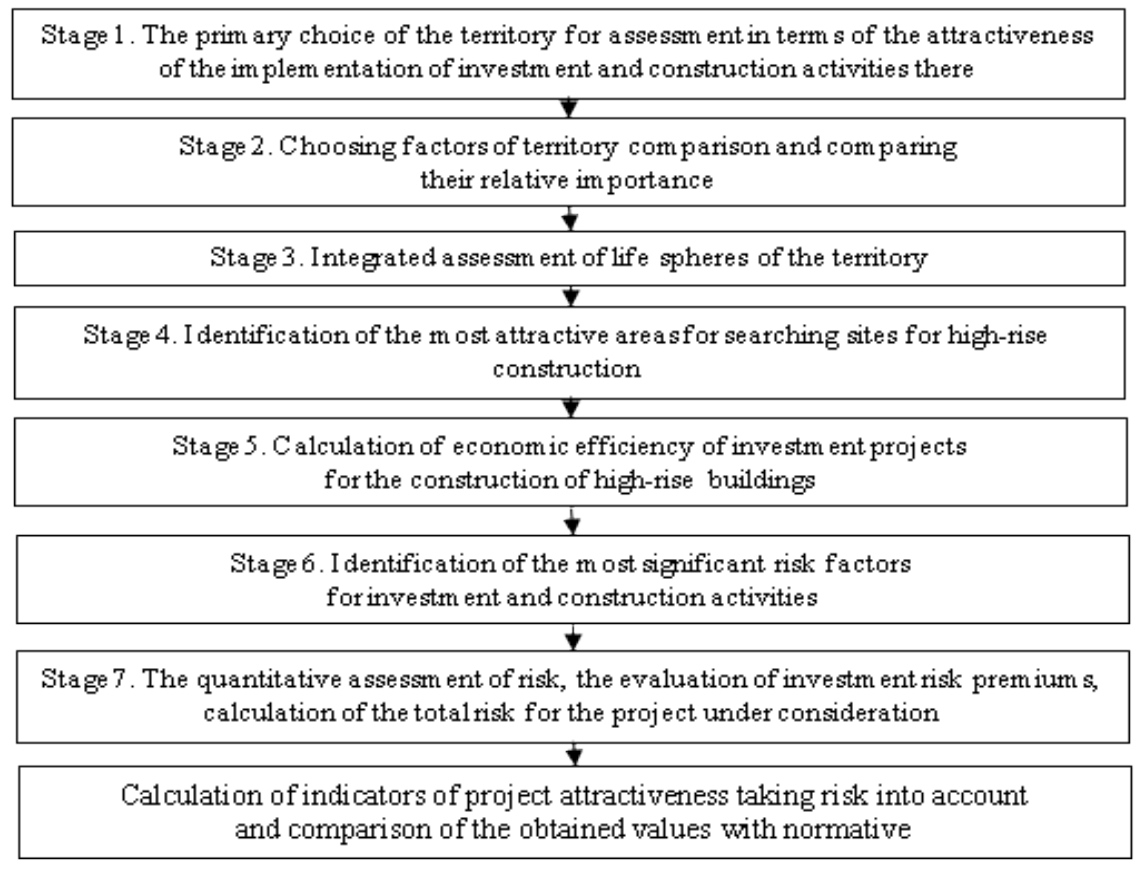

Fig. 3. Algorithm for evaluating the investment attractiveness of high-rise construction projects 
Some of these stages are obvious and standard, others need special explanations [5].

Stage 1. The first stage implies consideration of areas with the greatest concentration of quantitative housing demand.

Stage 2. This stage implies the use of the method of deducing 3 indexes: the index of the non-movable market level, indexes of the socio-economic and socio-demographic spheres of the regions' life-activity.

Stage 3. In the context of further evaluation, indicators that have a negative value, such as "unemployment rate", were given negative scores, because these indicators are disincentives of investment activity.

When creating scoring, in addition to the initial data on the values of the indicators, a scale was set to estimate each indicator. To calculate the scoring using the continuous scale, the following formulas were used:

For driver indexes:

$$
b_{i j}=b_{\min j}+\left(b_{\min j}-b_{\max j}\right) *\left(x_{i j}-x_{\min j}\right) /\left(x_{\min j}-x_{\max j}\right)
$$

For disincentive indexes:

$$
b_{i j}=b_{\max j}-\left(b_{\min j}-b_{\max j}\right) *\left(x_{i j}-x_{\min j}\right) /\left(x_{\min j}-x_{\max j}\right)
$$

where $b_{\max j}$ and $b_{\min j}$ are respectively the maximum and minimum possible scores for the $\mathrm{j}$-th index according to the scale accepted for it (in our case, from 1 to 10 ); $x_{\max j}$ and $x_{\min j}$ - respectively, the maximum and minimum value of the $\mathrm{j}$-th index when assessing the sphere of the i-th regions.

The complex estimate (index) of the investigated spheres was calculated by the formula (3):

$$
I_{i}=\sum_{j=1}^{n} D_{j} * b_{i j}
$$

where $I_{i}$ is the complex cumulative score (index) of the i-th region in the investigated sphere of life; $b_{i j}$ is the score of the region in the $\mathrm{j}$-th indicator; $D_{j}$ is the specific weight of the $\mathrm{j}$-th index in the integral estimation of the investigated sphere; $j \ldots . n$ - number of indicators.

Based on calculated complex comparative assessments, each region is assigned a certain place in the field under study.

Stage 4. Based on the indicators obtained at the previous stage, the territories are ranked, which makes it possible to select the most prospective for the deeper comparison from the previously proposed list.

Stage 5. The calculation of the economic efficiency of investment projects for the construction of high-rise buildings in the regions selected earlier is performed on the basis of standard investment analysis methods and involves the estimation of NPV and IRR.

Stage 6. In the developed methodology, an important role is played by risk factors that are associated with the economic, political and social situation of individual administrative or geographical regions. Their classification, taking into account the specifics of the

\begin{tabular}{|c|c|c|}
\hline Group of risks & Type of risk & $\begin{array}{c}\text { Brief description } \\
\end{array}$ \\
\hline \multirow[b]{2}{*}{$\begin{array}{l}\text { Socio- } \\
\text { economic risks }\end{array}$} & $\begin{array}{l}\text { Change in income } \\
\text { of the population }\end{array}$ & $\begin{array}{l}\text { In different periods of time, the population may not be } \\
\text { able to pay. }\end{array}$ \\
\hline & $\begin{array}{l}\text { Using mortgage } \\
\text { services }\end{array}$ & $\begin{array}{l}\text { High interest rate on a mortgage loan, impossible for } \\
\text { most of the population. }\end{array}$ \\
\hline $\begin{array}{l}\text { Risks of the } \\
\text { construction } \\
\text { industry }\end{array}$ & $\begin{array}{l}\text { Change in demand } \\
\text { for housing }\end{array}$ & $\begin{array}{l}\text { The competitiveness of high-rise buildings is determined } \\
\text { by the surrounding environment and the specificity of } \\
\text { individual preferences of buyers. }\end{array}$ \\
\hline
\end{tabular}
construction industry, is given in Table. 1.

Table 1. List of main regional risks for the construction company 


\begin{tabular}{|c|c|c|}
\hline \multirow[t]{7}{*}{$\begin{array}{l}\text { (sector- } \\
\text { specific risks) }\end{array}$} & Rivalry & $\begin{array}{l}\text { The main content of rivalry is the struggle for complete } \\
\text { satisfaction of the needs of the consumer. }\end{array}$ \\
\hline & $\begin{array}{l}\text { Availability } \\
\text { land plots }\end{array}$ & $\begin{array}{l}\text { The scarcity of land is connected with the lack of or } \\
\text { poorly prepared infrastructure for new construction }\end{array}$ \\
\hline & $\begin{array}{l}\text { State } \\
\text { engineering } \\
\text { infrastructure }\end{array}$ & $\begin{array}{l}\text { The scarcity of land is connected with the lack of or } \\
\text { poorly prepared infrastructure for new construction }\end{array}$ \\
\hline & $\begin{array}{l}\text { Legal } \\
\text { regulatory } \\
\text { framework }\end{array}$ & $\begin{array}{l}\text { The risk of increasing the time for obtaining all necessary } \\
\text { town planning documentation for design and } \\
\text { construction. }\end{array}$ \\
\hline & Human Resources & $\begin{array}{l}\text { Lack of qualified personnel in the region. Low proportion } \\
\text { of the able-bodied population. Deficiency of workers for } \\
\text { construction }\end{array}$ \\
\hline & $\begin{array}{l}\text { Development of } \\
\text { the construction } \\
\text { industry }\end{array}$ & $\begin{array}{l}\text { High cost of building materials. Shortage and } \\
\text { deterioration of machines and mechanisms. Absence of } \\
\text { "good" contractors for design and construction works }\end{array}$ \\
\hline & $\begin{array}{l}\text { Types } \\
\text { construction }\end{array}$ & $\begin{array}{l}\text { The predominance of low-rise buildings (low profit for } \\
\text { construction companies). Risk of non-viability of the } \\
\text { project and risk of non-completion of construction. }\end{array}$ \\
\hline \multirow{3}{*}{ Financial risks } & Bank interest rates & $\begin{array}{l}\text { High rates for bank loans, with the use of borrowed } \\
\text { funds. }\end{array}$ \\
\hline & Tax rates & High tax rates, incl. rent for land, etc. \\
\hline & $\begin{array}{l}\text { The rate } \\
\text { inflation }\end{array}$ & High inflation rate \\
\hline \multirow[b]{2}{*}{$\begin{array}{l}\text { Macroeconomi } \\
\text { c risks }\end{array}$} & $\begin{array}{l}\text { Geographical } \\
\text { location }\end{array}$ & $\begin{array}{l}\text { Unfavorable or least profitable economic and } \\
\text { geographical position of the region }\end{array}$ \\
\hline & Climat & $\begin{array}{l}\text { The harsh climate leads to an increase in the cost of } \\
\text { construction. The longevity of the house under } \\
\text { construction depends on the quality of the soil research in } \\
\text { the construction site. }\end{array}$ \\
\hline
\end{tabular}

Stage 7. A methodology similar to the country risk expert assessment, widely used to determine the discount rate in the valuation of a business, was offered to be used as a quantitative tool for assessing regional risks that could be used in further calculations.

For risk assessment (C), individual risk factors are suggested to be assessed in the range from $1 \%$ (minimum risk) to $10 \%$. Evaluation of the importance of this or that factor is carried out by the expert way and gives an opportunity to focus experts' attention on different factors of regional differences that are most interesting for a particular enterprise in a particular situation [6].

The total value of regional risk is determined by the formula:

$$
C=\frac{r^{*} e}{\sum_{i=1}^{10}} N i * R i,
$$

where $N_{i}$ is the number of observations of the $i$-th degree of risk; $R_{i}$ is the value of the degree of risk (from $1 \%$ to $10 \%$ ); $r$ is a number of risk factors; $e$ is a number of experts.

As a basic region in the methodology, it is proposed to use the region of primary placement of the company planning territorial expansion of its activities.

Stage 8. To assess the attractiveness of the region, it is proposed to use indicators of net present value and internal rate of return and to adjust them to the degree of investment risk.

The total risk adjustment is calculated using the following formula:

$$
R=B+C
$$


where $B$ is a corporate business risk, a risk premium for investing in a particular company; $C$ is a- regional risk.

The index of attractiveness of the investment project is calculated according the following formula:

$$
A^{*}=\frac{A}{(1+R)}
$$

where $A$ is the selected economic indicator; $R$ is the total amount of risk.

The values of $A^{*}$ obtained must be greater than or equal to the corresponding normative values adopted in the company, taking into account the experience and existing practice in implementing investment projects for high-rise construction.

\section{Discussions}

The attractiveness and economic reasonability of high-rise construction is determined by the development level of the territory where the project is planned to be implemented. The complexity here is to choose an alternative; which means to choose the territory more preferred for investing in a high-rise construction project [7]. Strengthening competition and the gradual saturation of demand in the construction market of megacities around the world make the largest construction corporations diversify their business, directing development to certain regional market sectors.

\section{Conclusion}

The need for methodological support of territory development is becoming increasingly important under the condition of continuing consolidation and growth of business, as it occurs in the construction industry. The development of high-rise construction requires new assessment approaches that make this development the most effective and sustainable for each particular construction company, allowing to assess adequately the possible risks and neutralize them.

\section{References}

1. I.V. Ilin, A.I. Levina, O.Yu. Iliashenko, MATEC Web of Conf., 106, 08066 (2017) DOi-10.1051/matecconf/201710608066

2. V. Kankhva, Procedia Engineering 165 1300-1304 doi:10.1016/j.proeng.2016.11.855

3. A. Jones, G. Fallon, R. Golov European Business Review, 12-4, pp.187-197, doi. 10.1108/09555340010336871

4. A. Bril, O. Kalinina, O. Valebnikova, Lecture Notes in Computer Science, 9870, pp 766-775 (2016) DOi -10.1007/978-3-319-46301-8_67

5. A.K. Orlov I.Y. Chubarkina MATEC Web of Conferences 08015106 pp (2017)

6. R Golov, V. Shilov, S. Silantiev ASEE International Forum, Columbus, Ohio. June 28, 2017. Paper ID \#20766.

7. E. Nezhnikova. IOP Conf. Series: Earth and Environmental Science 90012161 (2017) doi:10.1088/1755-1315/90/1/012161 